\title{
Effects of Coumarin, Pyronin Y, 6,9-Dimethyl 2-Methylthiopurine and Caffeine on Excision Repair and Recombination Repair in Escherichia coli
}

\author{
By G. W. GRIGG \\ C.S.I.R.O., Division of Animal Genetics, P.O. Box 90, \\ Epping, N.S.W. Australia, $2 \mathrm{I} 2 \mathrm{I}$ \\ (Accepted for publication I4 October I97I)
}

\begin{abstract}
SUMMARY
Pyronin Y (0.06 and 0. $16 \mathrm{~mm}$ ), coumarin (2 and $4 \mathrm{~mm}$ ), 6,9-dimethyl 2-methylthiopurine $(2 \mathrm{mM})$ and caffeine $(8 \mathrm{~mm})$, strongly inhibit Uvr repair (presumed excision repair) of u.v. lesions in Escherichia coli. With $0.16 \mathrm{~mm}$-pyronin $\mathrm{Y}$ or 4 mM-coumarin, one thymine dimer was a lethal event in the KI2 strain JC2926 rec $A-I_{3}$ and one to three dimers in the B/r derivative WP-2 rec $A-13$ and the $\mathrm{B} \operatorname{exr} A$ derivative Bs-2. Neither these compounds nor $8 \mathrm{~mm}$-caffeine had a significant effect on the survival of irradiated bacteria of the corresponding $u v r$ strains WP-2 Hcr-, BS-I2, and Bs- 8 . I suggest that $8 \mathrm{~mm}$-caffeine, $0 \cdot 16 \mathrm{~mm}$-pyronin Y, $4 \mathrm{~mm}$-coumarin and 2 mM-6,9-dimethyl 2-methylthiopurine selectively block excision repair without substantially affecting recombination repair.

Caffeine at $\mathrm{I} 2 \mathrm{~mm}$ only slightly depressed the viability of a u.v.-irradiated culture of WP-2 $\mathrm{Hcr}^{-}$or BS-12, but at $16 \mathrm{~mm}$ there was a much greater effect, particularly at low u.v. doses $\left(<40 \mathrm{ergs} / \mathrm{mm}^{2}\right)$. Since excision repair appeared to be effectively blocked by 8 mM-caffeine, the depression of u.v. survival of the $u v r$ mutants by $16 \mathrm{~mm}$-caffeine was presumed to be due to interference with recombination repair (Witkin \& Farquharson, 1969).
\end{abstract}

\section{INTRODUCTION}

The ultraviolet (u.v.) photoproducts of principal biological significance in Escherichia coli are pyrimidine dimers in DNA which interfere with normal DNA replication, and may lead to cell death (Setlow, I968).

Escherichia coli can cope with these lesions in the dark in at least two ways. In one, passage of the replicating fork past pyrimidine dimers in a priming strand results in a series of gaps in the freshly replicated strand, presumably because the dimers are unable to direct the insertion of nucleotides into the growing polynucleotide. The existence of discontinuities in the latter is thought to initiate recombination between daughter DNA strands permitting the reconstruction of the strands (Rupp \& Howard-Flanders, 1968). This is referred to as 'recombination repair'. Two genes with alleles giving an impaired recombination repair effectiveness are $\operatorname{rec} A-13$ and $\operatorname{exr} A$.

The other dark repair system involves the excision of pyrimidine dimers from the DNA and is termed excision repair. uvr Mutants are defective in this function.

Some years ago caffeine ( 5 to $10 \mathrm{mM}$ ) was shown to inhibit dark repair (Witkin, 1958), and more recently excision repair (Setlow \& Carrier, 1968). In vitro it neither inhibits DNA polymerase I activity (at a concentration of up to $100 \mathrm{mM}$, Grigg, 1968) nor the excision endonuclease isolated by Carrier \& Setlow (1970). Excision repair in vivo is inhibited by 
caffeine, however, so either different enzymes are involved in vivo or caffeine inhibits the endonuclease or exonuclease activity of Kornberg's enzyme in vivo (Kelly, Atkinson, Huberman \& Kornberg, 1969). A number of factors other than caffeine interfere with dimer excision. These include crystal violet, acriflavine (Feiner \& Hill, 1963; Setlow, 1964) cyanide, and starvation (Setlow \& Carrier, 1968).

The exact effects of caffeine on recombination repair are less obvious. Caffeine $\leqslant 10 \cdot 7 \mathrm{~mm}$ had very little effect on the u.v. survival of the $u v r A$ mutant WP-2 $\mathrm{Hcr}^{-}$, which implies that the independent recombination-repair pathway was unaffected (Sideropoulos \& Shankel, I968; Witkin \& Farquharson, 1969), although 10.7 mM-caffeine seems to depress normal recombination frequency in Escherichia coli (Witkin \& Farquharson, 1969). Harm (I967) reported that 4 mM-caffeine depressed the survival of u.v.-irradiated $B$ syn (uvr $C$, Strauss, I968) cells. Survival of u.v.-irradiated bacteria of the $u v r B$ (and $\operatorname{exr} A$ ) strain Bs-I was aided by the presence of $10.7 \mathrm{mM}$-caffeine in the post-irradiation incubation medium when the u.v. dose was $<\mathrm{I} 8 \mathrm{ergs} / \mathrm{mm}^{2}$. Above this dose caffeine inhibited recovery, and Harm suggested that the $u v r$ strains he studied exhibited residual $u v r^{+}$activity.

In this paper several compounds of low toxicity are described which selectively inhibit Uvr repair (presumed excision repair) and the effects of caffeine on u.v. survival of several uvr mutants are re-examined. The active compounds share the common characteristic that they bind selectively to denatured DNA.

\section{METHODS}

Bacteria. The bacteria used and their characteristics are shown in Table I.

Culture media. G.T. - a modified Gray and Tatum glucose salts medium (for composition see Grigg, 1969). BAB - Oxoid Blood Agar Base - a broth agar plating medium. TNM buffer - tris, O.I M; $\mathrm{NaCl}, 0 . \mathrm{I} 5 \mathrm{M} ; \mathrm{MgSO}_{4} \cdot 7 \mathrm{H}_{2} \mathrm{O}$, 0.0I M; adjusted to $\mathrm{pH} 7 . \mathrm{I}$. TI diluent -

Table I.

\begin{tabular}{|c|c|c|c|c|c|c|c|c|c|}
\hline \multirow[b]{2}{*}{ Strain } & \multicolumn{5}{|c|}{ Genotype } & \multirow{2}{*}{$\begin{array}{l}\text { Dimer } \\
\text { excision } \\
\text { status }\end{array}$} & \multirow{2}{*}{$\begin{array}{l}\text { Recom- } \\
\text { bination } \\
\text { repair } \\
\text { status }\end{array}$} & \multirow{2}{*}{ Reference/origin } & \multirow[b]{2}{*}{ Source } \\
\hline & lon & rad & $u v r$ & $\begin{array}{l}r e c \\
A-13\end{array}$ & $\operatorname{exr} A$ & & & & \\
\hline WP-2 & - & - & + & + & + & $++t$ & +++ & $\begin{array}{l}\text { Witkin, I947; } \\
\text { Donch, Chung \& } \\
\text { Greenberg, I968; } \\
\text { Donch, Green \& } \\
\text { Greenberg, 1968 }\end{array}$ & $\begin{array}{l}\text { Ruth Hill, ex } \\
\text { E. M. Witkin }\end{array}$ \\
\hline WP-2 $\mathrm{Hcr}^{-}$ & - & - & $-\mathrm{A}$ & + & + & $\mathrm{O}$ & ++ & $\begin{array}{l}\text { Donch \& } \\
\quad \text { Greenberg, } 1969\end{array}$ & Ruth Hill \\
\hline WP-2 rec $A$ & - & - & + & - & + & +++ & $\mathrm{O}$ & $\begin{array}{l}\text { Conjugation of } \\
\operatorname{rec} A \text { into wP-2 }\end{array}$ & $\begin{array}{l}\text { B. A. Bridges and } \\
\text { Ann Rothwell }\end{array}$ \\
\hline B & - & + & + & + & + & +++ & +++ & $\begin{array}{l}\text { Donch \& } \\
\text { Greenberg, I968 }\end{array}$ & Ruth Hill \\
\hline BS- 8 & - & - & $-\mathbf{B}$ & + & + & $\mathrm{O}$ & +++ & $\begin{array}{l}\text { Donch \& } \\
\quad \text { Greenberg, I968 }\end{array}$ & Ruth Hill \\
\hline BS-I 2 & - & + & -12 & + & + & $\mathrm{O}$ & $+t+$ & $\begin{array}{l}\text { Donch \& } \\
\text { Greenberg, I968; } \\
\text { Hill \& Feiner, I96 }\end{array}$ & $\begin{array}{l}\text { Ruth Hill } \\
54\end{array}$ \\
\hline BS-2 & - & + & + & + & - & $+t+$ & + & $\begin{array}{l}\text { Donch, Green \& } \\
\text { Greenberg, } 1968\end{array}$ & Ruth Hill \\
\hline JC2926 & + & $\mathrm{U}$ & + & - & + & $\mathrm{U}$ & $\mathrm{O}$ & & A. J. Clark \\
\hline
\end{tabular}


nutrient broth (Difco), $0.8 \mathrm{~g} ; \mathrm{NaCl}, 0.58 \mathrm{~g} ; \mathrm{H}_{2} \mathrm{O}$, I 1. TI agar - tryptone (Difco), Io g; agar (Difco), II g; $\mathrm{NaCl}, 0.58 \mathrm{~g} ; \mathrm{H}_{2} \mathrm{O}$, I l. TI soft agar-nutrient broth (Difco), $8 \mathrm{~g}$; agar (Difco), $7 \mathrm{~g} ; \mathrm{NaCl}, 0.58 \mathrm{~g} ; \mathrm{H}_{2} \mathrm{O}, \mathrm{I} 1$.

\section{Cultural methods}

An overnight culture was grown up in G.T. to exhaustion of the glucose in the medium. The resultant stationary phase culture was washed with $0.9 \%$ saline and resuspended in either saline or TNM buffer at a concentration of about $3 \times 10^{7}$ bacteria $/ \mathrm{ml}$. Portions (3.ml) were irradiated in a $5 \mathrm{~cm}$ diameter Petri dish with a $15 \mathrm{~W}$ cold cathode u.v. tube (Oliphant, Sydney, Australia) at a dose rate of 157,8 or I ergs $/ \mathrm{mm}^{2} / \mathrm{s}$ in a small cabinet with a camera shutter (Shanel $5 \mathrm{~A}$ ) installed in a septum between the u.v. lamp and the bacterial suspension. After irradiation the bacterial suspension was immediately diluted in saline, $0.2 \mathrm{ml}$ portions were spread on BAB plates and then incubated at $37^{\circ}$.

In host cell reactivation experiments a suspension of TI phage in TNM buffer (about $4 \times 10^{7}$ p.f.u./ml) was irradiated at a dose rate of $157 \mathrm{ergs} / \mathrm{mm}^{2} / \mathrm{s}$ for $10,20,40$ or $60 \mathrm{~s}$. Irradiated and unirradiated samples were diluted in $T_{I}$ phage diluent and samples of appropriate dilutions added to $3 \mathrm{ml}$ of $\mathrm{Tr}$ soft agar containing the compound being tested and about $10^{8} \log$ phase WP-2 bacteria. The soft agar suspension was then poured over the surface of TI agar, also containing the compound being tested, in a Petri dish. The plates were incubated at $37^{\circ}$ and the resulting Ti plaques scored.

Chemicals. The compounds tested for their biological activity were pyronin Y (G. Gurr, London), coumarin (E. Merk, Ag., Darmstatt, W. Germany), caffeine (Evans Medical Ltd, Liverpool) and 6,9-dimethyl 2-methylthiopurine (a gift from Dr D. Brown, Department of Medical Chemistry, Australian National University).

\section{RESULTS}

Effects of coumarin, pyronin Y, 6,9-dimethyl 2-methylthiopurine

The lethal effect of u.v. irradiation on Escherichia coli WP-2 was enhanced when the irradiated bacteria were incubated on BAB medium containing coumarin ( $2 \mathrm{mM}$ or $4 \mathrm{~mm}$ ), $8 \mathrm{~mm}$-caffeine or $0.16 \mathrm{~mm}$-pyronin Y (Fig. I). None of these substances depressed the survival of unirradiated control bacteria, but the growth rate was slightly lower on the coumarin medium.

Coumarin inhibited host cell reactivation (HCR) of TI phage by strain WP-2 (Fig. 2). Since this phenomenon seems correlated with excision-repair, experiments were performed on strains defective in excision-repair, WP-2 $\mathrm{Hcr}^{-}(u v r A$ ), or recombination repair, WP-2 rec $A-I_{3}$, both to check the ability of coumarin and the other compounds to inhibit Uvrrepair and to test their effect on recombination repair. A lower survival of u.v.-irradiated $u v r^{-}$bacteria on medium containing the test compound, e.g. coumarin, would indicate that the latter inhibited the other dark-repair process, recombination repair, whereas a similar result with a recombination-defective culture would indicate that it inhibited $\mathrm{Uvr}^{-}$(excision) repair, provided that both classes of repair-defective mutants were nonleaky.

Coumarin and pyronin $\mathrm{Y}$ depressed the survival of u.v.-irradiated cultures of the WP-2 rec $A$ strain, particularly at low u.v. doses (Fig. I). Unirradiated WP-2 rec $A$ cells proved extremely sensitive to $8 \mathrm{~mm}$-caffeine and no useful data were obtained with this additive. Coumarin, pyronin $\mathrm{Y}$ and $8 \mathrm{~mm}$-caffeine had little effect on the sensitivity of WP-2 $\mathrm{Hcr}^{-}$ bacteria ( $u v r A$ ) to u.v. doses $<6 \mathrm{ergs} / \mathrm{mm}^{2}$ although a small effect was apparent at higher 

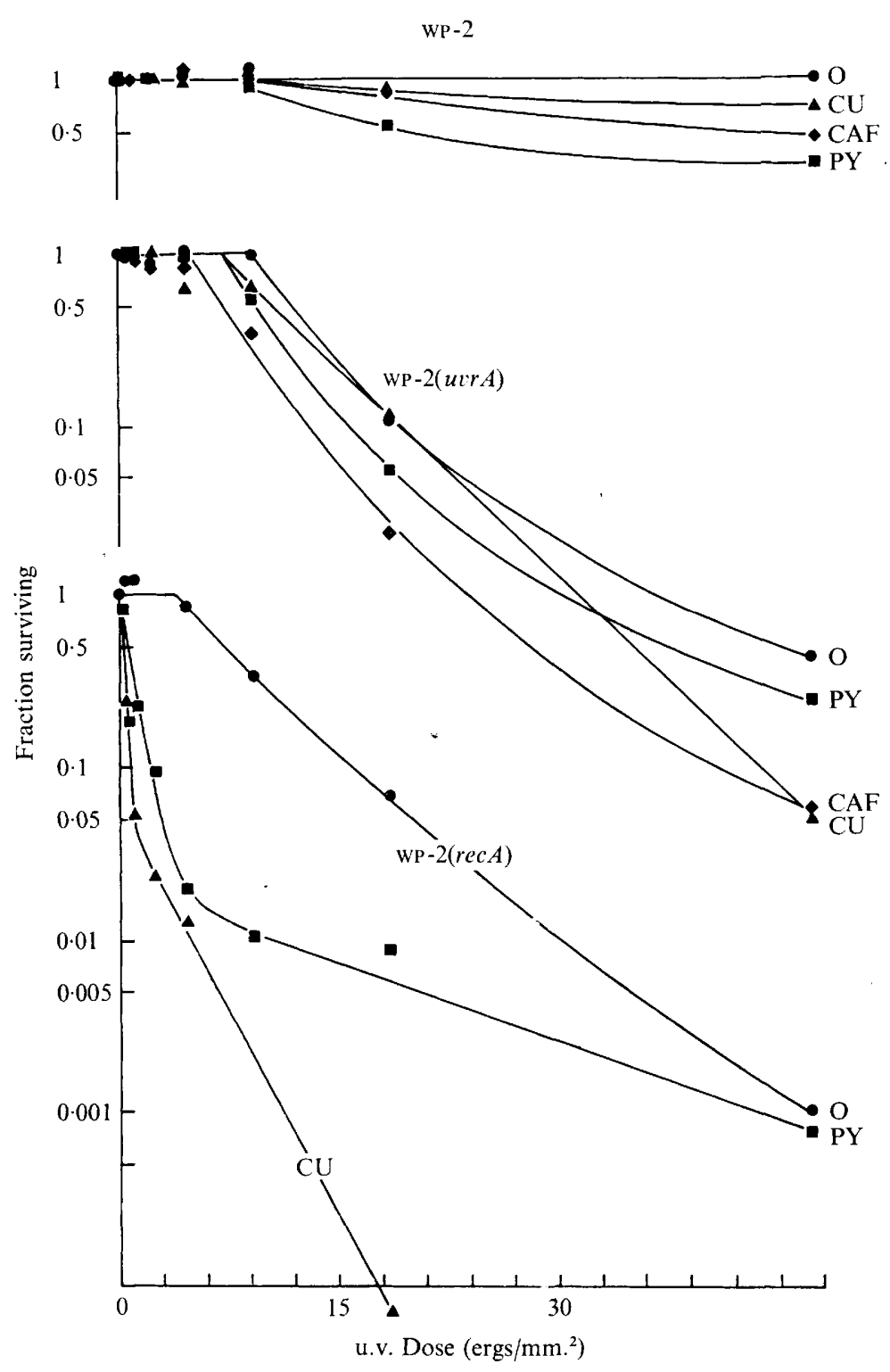

Fig. I. u.v. Survival of wP-2, wP-2 $\mathrm{Hcr}^{-}(u v r A)$ and wP-2 $\operatorname{rec} A$ bacteria on BAB medium supplemented with nothing (O), $8 \mathrm{~mm}$-caffeine (CAF), $0.16 \mathrm{~mm}$-pyronin Y (PY), $4 \mathrm{~mm}$-coumarin (CU). All bacteria were irradiated in stationary phase of growth.

doses particularly with 8 mM-caffeine (Fig. I). Similar results were obtained with strains of the Escherichia coli в family (Fig. 3). Thus u.v. survival of bacteria of the $u v r-I 2$ strain Bs-I2 was unaffected by post-irradiation exposure to coumarin $(4 \mathrm{mM}), 6,9$-dimethyl 2-methylthiopurine ( $2 \mathrm{~mm}$ ) or caffeine $(8 \mathrm{~mm})$. Pyronin Y slightly suppressed survival over the u.v. dose range 3 to $29 \mathrm{ergs} / \mathrm{mm}^{2}$. On the other hand, a considerable drop in u.v. survival of the recombination defective $(\operatorname{exr} A)$ Bs-2 bacteria occurred if they were exposed to any of these compounds. That the effect was not limited to cells having a strain B or WP-2 


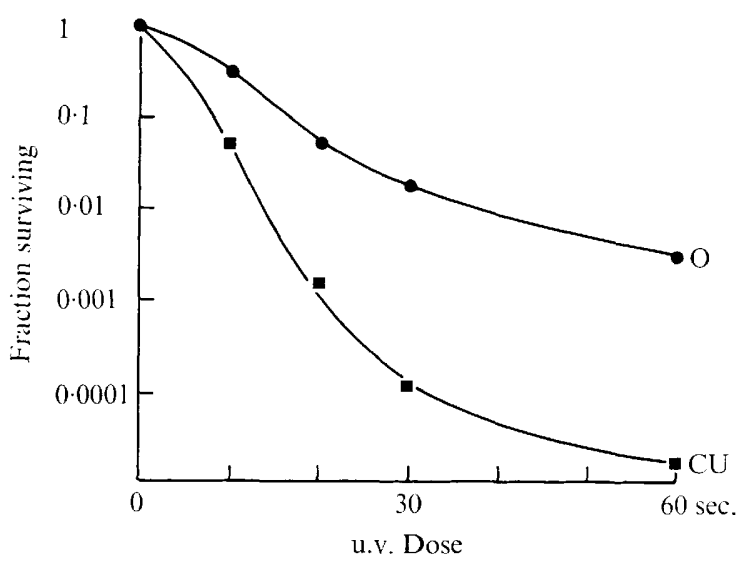

Fig. 2. Host cell reactivation of u.v.-irradiated Tl phage by wP-2 bacteria on medium supplemented with nothing (O) or coumarin (4 mM) (CU). u.v. Dose rate $157 \mathrm{ergs} / \mathrm{mm}^{2} / \mathrm{sec}$.

background is indicated by the observation that pyronin $\mathrm{Y}$ and coumarin (the only compounds tested) also suppressed u.v. survival of the KI 2 rec A-r 3 strain JC2926 (Fig. 4). In fact, in the presence of these additives, approximately I pyrimidine dimer per chromosome appeared lethal to JC2926 bacteria and I-3 to WP-2 rec $A$ and в exr $A$ bacteria.

Of the compounds examined for their effects on u.v. survival, on the whole pyronin $\mathrm{Y}$ had the highest molar activity, particularly when assayed on strain в exr $A$ bacteria (Fig. 3). With the KI2 rec $A$ strain JC2926 and WP-2 rec $A 4$ mM-coumarin was more effective than 0.16 mM-pyronin $\mathrm{Y}$ but both compounds essentially inhibited all repair at low u.v. doses (Fig. 4). The greatest effect of all the substances tested was apparent at the lowest u.v. doses used (Fig. I, 3, 4), the depression of survival declining progressively with increasing u.v. dose.

The shoulder of the dose-survival curve at low u.v. doses represents the number of DNA lesions, mainly pyrimidine dimers, with which the cell can deal without loss of viability. Double $u v r, \operatorname{rec} A$ mutants lacking both dark repair capabilities require approximately one dimer to induce a lethal event (Howard-Flanders, Theriot \& Stedeford, 1969). From the data presented above, coumarin and $0.16 \mathrm{~mm}$-pyronin $\mathrm{Y}$ inhibit essentially all excision repair activity and 8 mM-caffeine and 6,9-dimethyl 2-methylthiopurine probably are as effective.

\section{Effects of caffeine}

Although $\leqslant 12 \mathrm{mM}$-caffeine had minimal effects on any of the $u v r$ mutants tested (Fig. I, $3,5), 16 \mathrm{~mm}$-caffeine depressed survival very significantly, particularly at low u.v. doses (Fig. 5). This high concentration of caffeine could be used with the uvr strains because of their relative resistance to the toxic effects of caffeine (Grigg, 1968). The effects of I6 mMcaffeine on survival after u.v. were reversible for at least $4 \mathrm{~h}$ following irradiation. Identical results were obtained with $u v r$ mutants having different genetic backgrounds including the uvr B rad strain Bs-8, the $u v r-12$ strain Bs-I2, and the $u v r$ A rad strain WP-I2 $\mathrm{Hcr}^{-}$. 


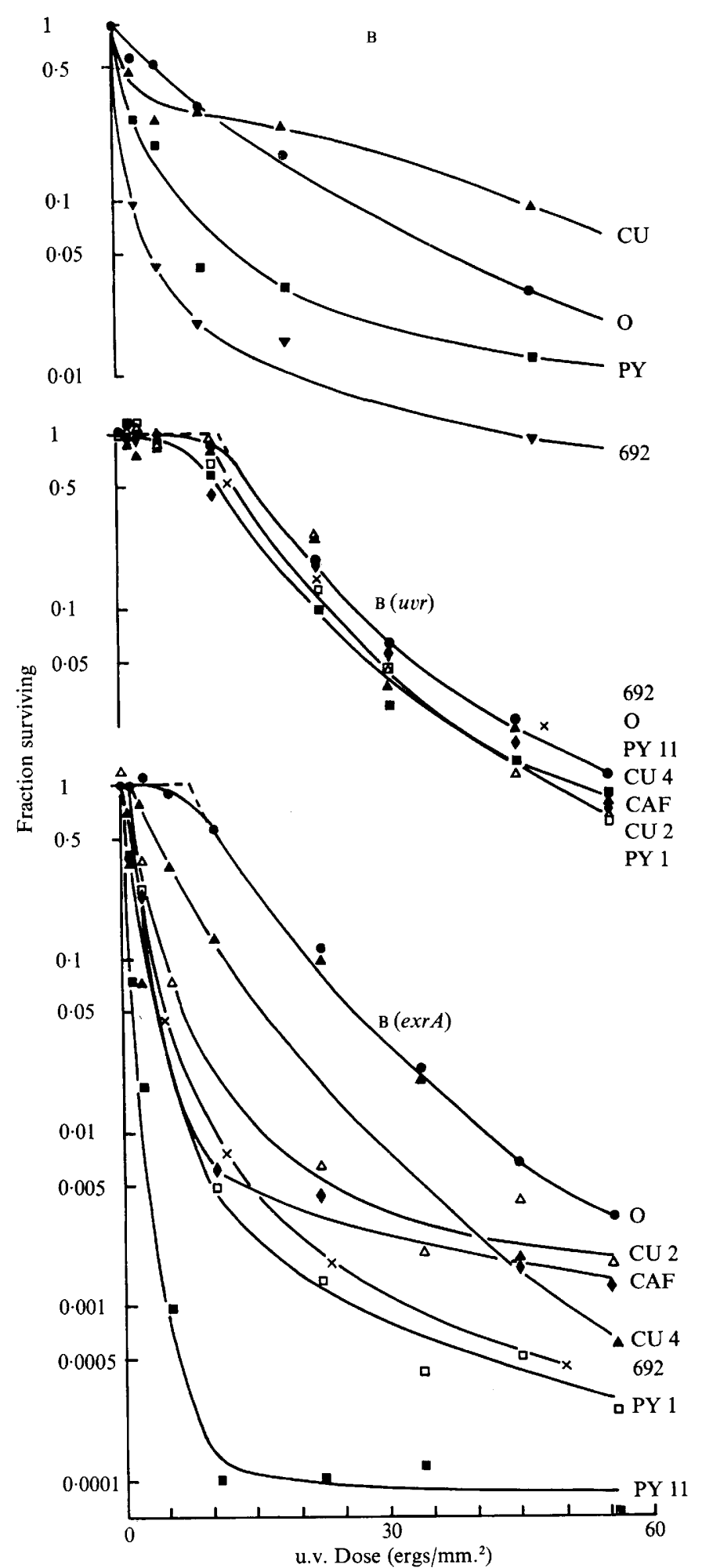

Fig. 3. U.v. Survival of Escherichia coli $\mathrm{B}, E$. coli в $u v r$ I2 (BS-I 2), E. coli в exr $A$ (BS-2) bacteria on BAB medium supplemented with nothing (O), $8 \mathrm{~mm}$-caffeine (CAF), 0.06 or $0.16 \mathrm{~mm}$ pyronin Y (PY I, PY II), 2 mM 6,9-dimethyl 2-methylthiopurine (692), 2 or 4 mM-coumarin (CU 2, CU 4). All bacteria were in stationary phase when irradiated. 


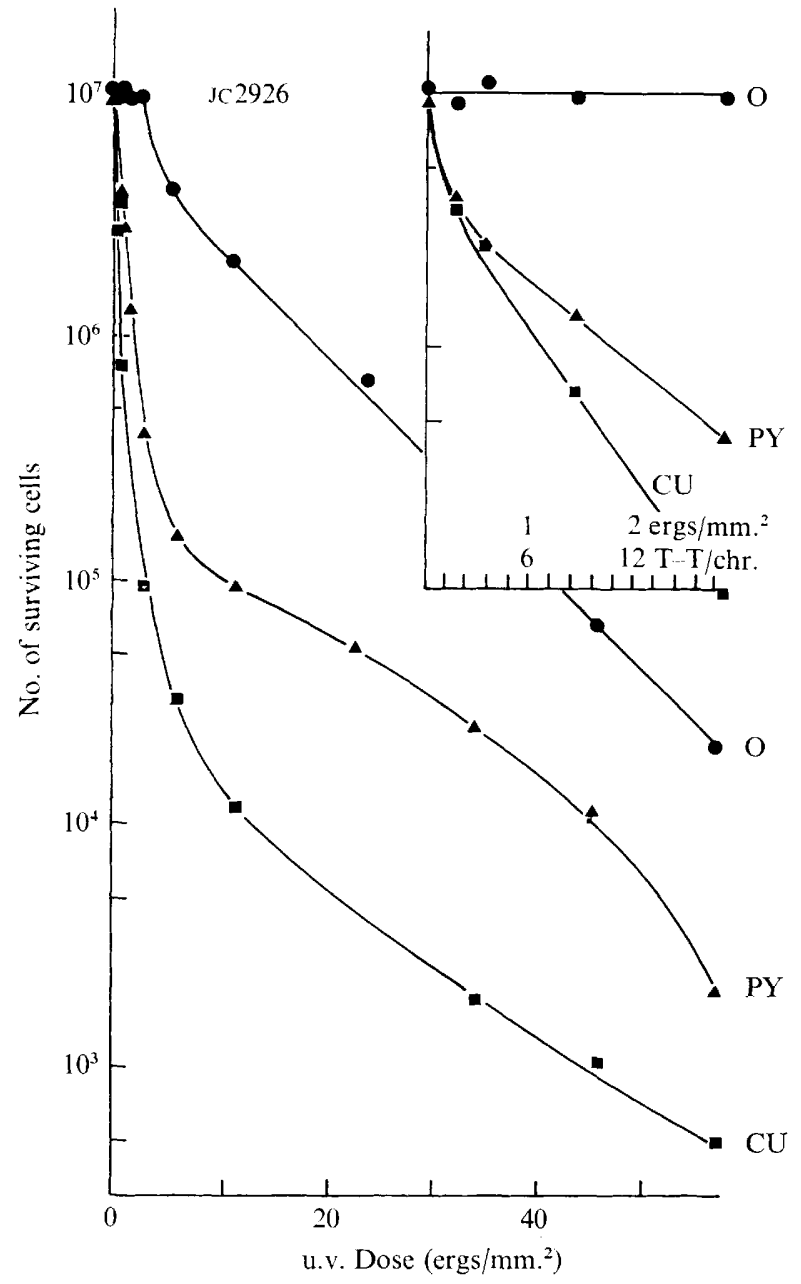

Fig. 4. u.v. Survival of stationary phase cells of the rec $A$-13 strain JC2926 on BAB medium supplemented with nothing $(\mathrm{O}) 0.16 \mathrm{~mm}$-pyronin $\mathrm{Y}(\mathrm{PY})$ or $4 \mathrm{~mm}$-coumarin $(\mathrm{CU})$. The bacteria were grown up to stationary phase in broth. The survival curves for small u.v. doses $\left(<2 \mathrm{erg} / \mathrm{mm}^{2}\right)$ are shown on an expanded dose scale in the insert. The calculated number of thymine dimers $(T-T)$ per chromosome generated by the u.v. dose is also indicated on the dose scale.

\section{DISCUSSION}

In the Escherichia coli WP-2 and B strains used in this study, coumarin ( 2 and $4 \mathrm{mM}$ ), pyronin $\mathrm{Y}(0 . \mathrm{I} 6$ and $0.04 \mathrm{~mm}), 6,9$-dimethyl 2-methylthiopurine $(2 \mathrm{~mm})$ and caffeine $(8 \mathrm{~mm})$ selectively inhibited the $u v r$ - (or excision-) repair process. The results with the KI 2 rec $A$ strain suggested that inhibition of excision repair occurs in this strain also. Although dissimilar chemically these compounds share with caffeine the ability to bind specifically to single-stranded DNA (T'so \& Lu, 1964; Grigg, Edwards \& Brown, I97I). Domon, Barton, Porte \& Rauth (1970) conclude that this property is important in explaining inhibition of excision repair by caffeine. The results reported here suggest that substances which exhibit selectivity of binding for single-stranded DNA may inhibit excision repair. As with caffeine, the mode of action could be by co-operative denaturation of regions of the DNA localized 


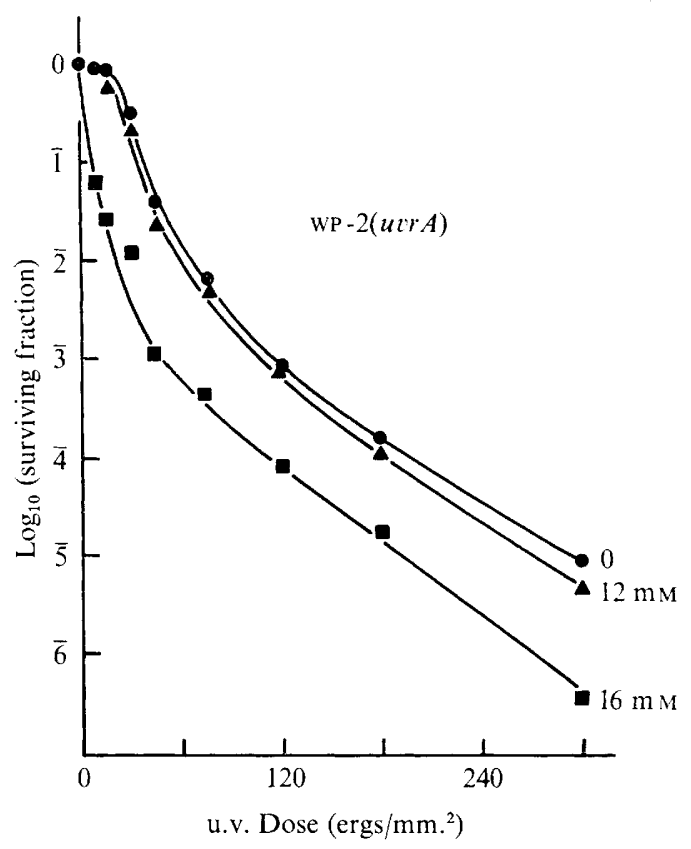

Fig. 5. u.v. Survival of stationary phase wP-2 $\mathrm{Hcr}^{-}(u v r A)$ bacteria on BAB medium containing 0,12 and 16 mm-caffeine.

around pyrimidine dimers where hydrogen bonding between the complementary strands of DNA was weakened. Since the endonuclease which initiates excision repair is a doublestrand specific enzyme, presumably it could not then recognize the substrate. The range of substances which share specific binding to single-stranded DNA is quite large and, apart from the compounds discussed above, includes steroids, naphthalene, phenanthrene (T'so \& Lu, 1964) and a number of the thio- and mercaptopurines (Grigg et al. 197I). The compounds used in the work reported here also share the ability to amplify the induction of DNA breakdown and cell death by Phleomycin (Grigg, I970). The order of ranking of the relative efficiencies as amplifying substances and as inhibitors of excision repair is somewhat different. As amplifiers, $0.16 \mathrm{~mm}$-pyronin $\mathrm{Y}$ is the most effective with the 2 mm-methylthiopurine second, then $4 \mathrm{~mm}$-coumarin and $8 \mathrm{~mm}$-caffeine a good way behind (Grigg et al. 197I), whereas, as inhibitors of excision repair, 0.16 mM-pyronin, 2 mM-coumarin, $2 \mathrm{mM}-$ 6,9-dimethyl 2-methylthiopurine and $8 \mathrm{~mm}$-caffeine have comparable efficiencies at low u.v. doses $\left(<8 \mathrm{ergs} / \mathrm{mm}^{2}\right)$.

Pyronin B, a compound closely related chemically and in its histological staining properties to pyronin Y, does not affect mutation frequency decline (MFD), unlike a number of other basic dyes (Witkin, I96I). MFD is thought to be associated with the excision of thymine dimers from the u.v.-irradiated DNA (Bridges, 1966; Witkin, 1966), and the observation that pyronin $\mathrm{Y}$ is an efficient inhibitor of excision repair may seem paradoxical. It would indicate that either pyronin $\mathrm{B}$ differs from pyronin $\mathrm{Y}$ and does not prevent thymine dimer excision from DNA, or the MFD phenomenon is not related in a simple fashion to the excision of thymine dimers.

Incubation of irradiated cells of Escherichia coli B strains in medium containing $8 \mathrm{~mm}-$ caffeine effectively suppressed excision repair. Consequently, the ability of a similar or higher concentration of caffeine to depress the survival of excision-defective strains of 
Escherichia coli в (Harm, 1967; and see above) may be explained best by the proposition that caffeine inhibits another dark repair process, recombination repair (Witkin \& Farquharson, I969), rather than by the conclusion that these uvr mutants are 'leaky', i.e. possess residual excision activity (Harm, 1967). Furthermore, if the excision-defective strains used by Harm are non-leaky then a reinterpretation of his data suggests that acriflavine also inhibits recombination repair.

Coumarin is used in the cosmetic and food industries as a scent and flavouring substance. The effectiveness of another coumarin in inhibiting excision repair has been observed recently by Bridges (197I). Since failure to remove thymine dimers from DNA may lead to the synthesis of antibodies to them (Tan, 1968) which, in laboratory animals at least, cross-react with normal DNA with possible serious side-effects (Cleaver, 1969), the trivial use of such potential or actual u.v.-sensitizing agents should be queried.

I am indebted to Mrs J. Smith, Mrs D. Bartels and Miss A. Angyal for their skilled assistance at various times in this work.

\section{REFERENCES}

BRIDGES, B. A. (1966). A note on the mechanism of u.v. mutagenesis in Escherichia coli. Mutation Research 3, 273-279.

BRIDGes, B. A. (I97I). Genetic damage induced by $254 \mathrm{~nm}$ ultraviolet light in Escherichia coli: 8-methoxypsoralen as protective agent and repair inhibitor. Photochemistry and Photobiology 14, 659-662.

Carrier, W. L. \& Setlow, R. B. (1970). Endonuclease from Micrococcus luteus which has activity towards ultraviolet-irradiated desoxyribonucleic acid: purification and properties. Journal of Bacteriology roz, I78-I 86.

CleAver, J. E. (1969). Xeroderma pigmentosum: a human disease in which an initial stage of DNA repair is defective. Proceedings of the National Academy of Science of the United States of America 63, 428-435.

Domon, M., BARTon, B., PorT, A. \& RAuth, A. M. (1970). The interaction of caffeine with u.v. irradiated DNA. International Journal of Radiation Biology and Related Studies in Physics, Chemistry and Medicine I7, 395-399.

Donch, J., Chung, Y.S. \& Greenberg, J. (I968). Locus for radiation resistance in Escherichia coli strain B/r. Genetics 6r, 363-370.

Donch, J., Green, M. H. \& Greenberg, J. (I968). Interaction of the exr and lon genes in Escherichia coli. Journal of Bacteriology 96, 1704-1710.

Donch, J. \& Greenberg, J. (1968). Genetic studies of strain BS-8 of Escherichia coli. Genetical Research $\mathbf{1 2}$, $55-63$.

DONCH, J. \& GREENBERG, J. (I969). Locus of the mutation responsible for the Her property of strain wP-2 her of Escherichia coli. Mutation Research 8, 658.

FeINer, R. \& Hill, R. (1963). Effect of basic dyes on host cell reactivation of ultraviolet irradiated phage. Nature, London 200, 291-293.

GrigG, G. W. (1968). Caffeine death in Escherichia coli. Molecular and General Genetics 102, 316-335.

GRIGG, G. W. (I969). Induction of DNA breakdown and death in Escherichia coli by Phleomycin. Molecular and General Genetics 104, I-I I.

GrigG, G. W. (1970). Amplification of Phleomycin induced death and DNA breakdown by caffeine in Escherichia coli. Molecular and General Genetics 107, 162-172.

Grigg, G. W., Edwards, M. \& Brown, D. (197I). Amplification of Phleomycin induced death and DNA breakdown by coumarin, thiopurines and pyronin Y. Journal of Bacteriology 107, 599-609.

HARM, W. (1967). Differential effects of acriflavine and caffeine on various ultraviolet irradiated Escherichia coli strains and $\mathrm{T}_{1}$ phage. Mutation Research 4, 93-I ro.

HILl, R. \& FEINER, R. (I964). Further studies of ultraviolet sensitive mutants of Escherichia coli B strains. Journal of General Microbiology 35, IO5-I I4.

Howard-Flanders, P., Theriot, L. \& Stedeford, J. B. (1969). Some properties of excision-defective recombination-deficient mutants of Escherichia coli K-I2. Journal of Bacteriology 97, I I 34-I I4I.

Kelly, R. B., Atkinson, M. R., Huberman, J. A. \& Kornberg, A. (1969). Excision of thymine dimers and other mismatched sequences by DNA polymerase of Escherichia coli. Nature, London 224, 495-50I. 
RuPP, W. D. \& Howard-Flanders, P. (I968). Discontinuities in the DNA synthesized in an excisiondefective strain of Escherichia coli following ultraviolet irradiation. Journal of Molecular Biology, 3I, 29I-304.

SetLow, R. B. (1964). Physical changes and mutagenesis. Journal of Cellular and Comparative Physiology 64 (Suppl. 1), 5I-64.

Setlow, R. B. (1968). Photoproducts in DNA irradiated in vivo. Photochemistry and Photobiology 7, 643$65 \mathrm{I}$.

SeTlow, R. B. \& CARRIER, W. L. (1968). The excision of pyrimidine dimers in vivo and in vitro. In Replication and Recombination of Genetic Material, pp. 13I-14I. Canberra: Australian Academy of Science.

Stderopoulos, A. S. \& Shankel, D. M. (1968). Mechanism of caffeine enhancement of mutations induced by sublethal ultraviolet dosages. Journal of Bacteriology 96, 198-204.

Strauss, B. (1968). DNA repair mechanisms and their relation to mutation and recombination. Current Topics. Microbiology and Immunology 44, I-85.

TAN, E. M. (I968). Antibodies to DNA irradiated with ultraviolet light: detection by precipitins and immunoffuorescence. Science, New York 16r, I353-1 354.

T'so, P. O. P. \& LU, P. (1964). Interaction of nucleic acids. I. Physical binding of thymine, adenine, steroids and aromatic hydrocarbon to nucleic acids. Proceedings of the National Academy of Science of the United States of America 5r, 17-24.

WitKIN, E. M. (1947). Genetics of resistance to radiation in Escherichia coli. Genetics 32, 22 I-248.

WITKIN, E. M. (1958). Post-irradiation metabolism and the timing of ultraviolet induced mutations in bacteria. Proceedings of the 1oth International Congress of Genetics, Montreal $\mathbf{x}, 280-299$.

WITKIN, E. M. (196I). Modification of mutagenesis initiated by ultraviolet light through post treatment of bacteria with basic dyes. Journal of Cellular and Comparative Physiology 58 (Suppl. I), I35-I 44.

WITKIN, E. M. (I966). Mutation and the repair of radiation damage in bacteria. Radiation Research Supplement 6, 30-53.

Witkin, E. M. \& Farquharson, E. L. (1969). Enhancement and diminution of ultraviolet-light initiated mutagenesis by post-treatment with caffeine in Escherichia coli. In Mutation as a Cellular Process, pp. 36-49. Ciba Foundation Symposium. Edited by G. E. W. Wolstenholme and M. O'Connor. London: J. and A. Churchill. 